The Nonprofit Sector 
This page intentionally left blank 


\section{THE NONPROFIT SECTOR}

A Research Handbook

THIRD EDITION

Edited by Walter W. Powell and Patricia Bromley 
STANFORD UNIVERSITY PRESS

Stanford, California

( 2020 by the Board of Trustees of the Leland Stanford Junior University. All rights reserved.

No part of this book may be reproduced or transmitted in any form or by any means, electronic or mechanical, including photocopying and recording, or in any information storage or retrieval system without the prior written permission of Stanford University Press.

Printed in the United States of America on acid-free, archival-quality paper

Library of Congress Cataloging-in-Publication Data

Names: Powell, Walter W., editor. | Bromley, Patricia, editor.

Title: The nonprofit sector : a research handbook / edited by Walter W. Powell and Patricia Bromley.

Description: Third edition. | Stanford, California : Stanford University Press 2020. | Includes bibliographical references and index.

Identifiers: LCCN 2019021227 | ISBN 9781503608047 (paperback) | ISBN 9781503611085 (epub)

Subjects: LCSH: Nonprofit organizations-Management. | Nonprofit organizations. | Charitable uses, trusts, and foundations.

Classification: LCC HD62.6 .N67 2020 | DDC 338.7/4-dc23

LC record available at https://lccn.loc.gov/2019021227

Cover design: Rob Ehle

Text design: Kevin Barrett Kane

Typeset by Newgen in 10/13 Minion Pro 